\title{
A role for neuropeptides in innate immune inflammation of the nose
}

\author{
Olivia Larsson ${ }^{1 *}$, Lotta Tengroth¹, Yuan Xu', Susanna Kumlien Georen ${ }^{1}$, Lars-Olaf Cardell ${ }^{2}$ \\ From The 10th Symposium of Experimental Rhinology and Immunology of the Nose (SERIN 2015) \\ Stockholm, Sweden. 19-21 February 2015
}

\section{Background}

The airway epithelium constitutes the first line of defense in the protection against invading pathogens. It acts as a barrier, but it is also is a major source of early released inflammatory mediators, which help shape the inflammatory response. Neuropeptides, such as substance P (SP), have long been considered to be early contributors to the inflammatory response, causing pain hypersensitivity and vasodilation, as well as activation and infiltration of various immune cells. Toll-like receptor 7 (TLR7) is found on the epithelial cells and is known to be activated by viruses. The present study has investigated the relationship between TLR7 activation/expression and SP release/ stimulation.

\section{Method}

Human nasal epithelial cells (HNEC) were obtained through nasal brushing of 6 healthy donors. The cells were cultured until passage 4 and thereafter stimulated with the TLR7 agonists R-837 or R-848 $(1,5$ or $10 \mu \mathrm{g} / \mathrm{ml})$ for $15 \mathrm{~min}, 30 \mathrm{~min}$ or $4 \mathrm{~h}$. The subsequent release of SP was analyzed with EIA. In addition, HNECs were stimulated with SP $(10,50$ or $100 \mathrm{nM})$ for 30 minutes in the presence or absence of NK-1 antagonist Aprepitant. Expression of Toll-like receptors was then determined using flow cytometry.

\section{Results}

HNECs produced substance $P$ in a concentrationdependent manner in response to both $\mathrm{R}-837$ and $\mathrm{R}-848$. Increased levels of SP were detected already after 15 minutes, and increased successively over time. SP stimulation increased not only the TLR7 expression in HNECs, but also expression of TLR1, 4 and 9 on these cells. Aprepitant effectively blocked this response.

${ }^{1}$ Karolinska Institutet, Division of ENT Diseases, CLINTEC, Stockholm, Sweden Full list of author information is available at the end of the article

\section{Conclusion}

The presented results suggest a role for SP in modulating the local innate immune response in the nose.

\section{Authors' details}

'Karolinska Institutet, Division of ENT Diseases, CLINTEC, Stockholm, Sweden. ${ }^{2}$ Karolinska Institutet and Karolinska University Hospital, Division of ENT Diseases, CLINTEC, Stockholm, Sweden.

Published: 26 June 2015

doi:10.1186/2045-7022-5-S4-O2

Cite this article as: Larsson et al:: A role for neuropeptides in innate immune inflammation of the nose. Clinical and Translational Allergy 2015 5(Suppl 4):O2.
Submit your next manuscript to BioMed Central and take full advantage of:

- Convenient online submission

- Thorough peer review

- No space constraints or color figure charges

- Immediate publication on acceptance

- Inclusion in PubMed, CAS, Scopus and Google Scholar

- Research which is freely available for redistribution
() Biomed Central

\section{Biomed Central}

